\title{
Open Biopsy of Kidney
}

National Cancer Institute

\section{Source}

National Cancer Institute. Open Biopsy of Kidney. NCI Thesaurus. Code C51732.

Removal of tissue from the kidney, for microscopic examination, performed during an open surgical procedure. 